\title{
Does Sequential Diabetes Dance Improve on Glucose Level and Glucose Tolerance? by Cynthia Wahyu Asrizal
}

Submission date: 18-Feb-2022 03:08PM (UTC+0800)

Submission ID: 1765286219

File name: 54._Artikel.pdf (19.53M)

Word count: 5604

Character count: 33390 


\section{SIPS SUинава INTERNATIONAL \\ 2017 pinsoloor SEMINAR}

\section{PROCEEDINGS OF}

THE SURABAYA INTERNATIONAL PHYSIOLOGY SEMINAR

Surabaya, October 12-14, 2017

\section{Editors:}

Soetjipto

Muhammad Miftahussurur

Ferry Efendi

Purwo Sri Rejeki

Bambang Purwanto

\section{SDI}




\section{SIPS 2017 \\ Proceedings of the \\ Surabaya International Physiology Seminar}

Surabaya - Indonesia

October 12 - 14, 2017 
Copyright $\odot 2018$ by SCITEPRESS - Science and Technology Publications, Lda. All rights reserved

Edited by Soetjipto, Muhammad Miftahussurrur, Ferry Efendi, Purwo Sri Rejeki and Bambang Purwanto

\author{
Printed in Portugal \\ ISSN: $2184-3678$ \\ ISBN: 978-989-758-340-7 \\ Depósito Legal: $446682 / 18$
}

http://sipsfk.conference.unair.ac.id

sipsiaifi2017@gmail.com 


\section{BRIEF CONTENTS}



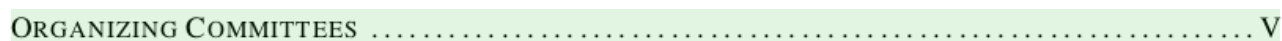

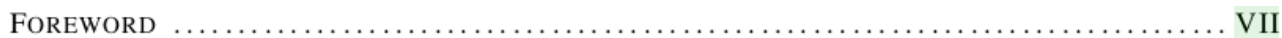

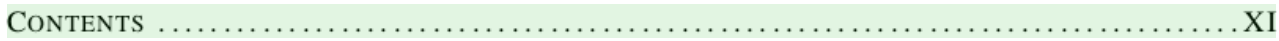




\section{INVITED SPEAKERS}

Cheng Hwee Ming

University of Malaya

Malaysia

Daniel John Green

University of Western Australia

Australia

Fadzil Hamzah

Sport Center of Changi General Hospital

Singapore

Deanne Helena Skelly

Griffith University

Australia 


\section{Organizing Committees}

\section{SCIENTIFIC Committee}

Cheng Hwee Ming, Department of Physiology, Faculty of Medicine, University of Malaya, Malaysia

Daniel John Green, University of Western Australia, Australia

Fadzil Hamzah, Changi Sports Medicine Centre, Changi General Hospital, Singapore

Deanne Helena Skelly, University of Western Australia, Australia

R. Soedarso Djojonegoro, Universitas Airlangga, Indonesia

Paulus Liben, Universitas Airlangga, Indonesia

Elyana Asnar STP, Universitas Airlangga, Indonesia

Choesnan Effendi, Universitas Airlangga, Indonesia

Harlina, Universitas Airlangga, Indonesia

Tjitra Wardani, Universitas Airlangga, Indonesia

Gadis Meinar Sari, Universitas Airlangga, Indonesia

Purwo Sri Rejeki, Universitas Airlangga, Indonesia

Lilik Herawati, Universitas Airlangga, Indonesia

Bambang Purwanto, Universitas Airlangga, Indonesia

Kristanti Wanito Wigati, Universitas Airlangga, Indonesia

Hayuris Kinandita Setiawan, Universitas Airlangga, Indonesia

Irfiansyah Irwadi, Universitas Airlangga, Indonesia

Sundari Indah Wiyasihati, Universitas Airlangga, Indonesia

Eka Arum Cahyaning Putri, Universitas Airlangga, Indonesia

Misbakhul Munir, Universitas Airlangga, Indonesia 


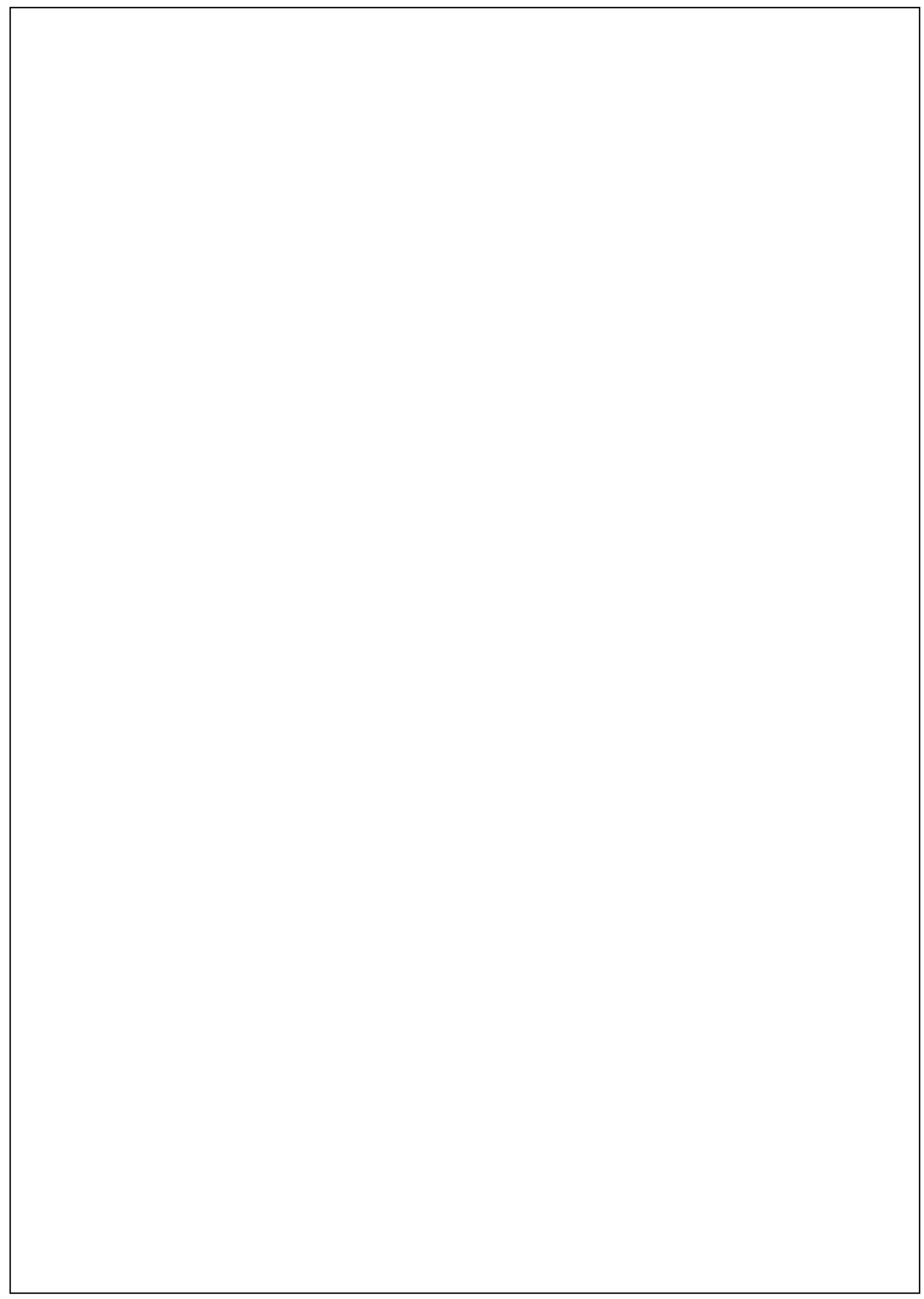




\section{FOREWORD}

\section{Dean of Faculty of Medicine, Universitas Airlangga}

Assalamu'alaikum Wr. Wb.

Distinguished Guests, all the Participants, Ladies and Gentlemen

On behalf of Faculty of Medicine, Universitas Airlangga, it is my great pleasure to welcome all the speakers, moderators, and participants on Surabaya International Physiology Seminar 2017 (SIPS 2017), which will be held from today, October 12th until October 14th, 2017. I would like to express my hearty welcome to all the international speakers, Prof. Cheng Hwee Ming, from University of Malaya, Malaysia; Prof. Daniel John Green, from University of Western Australia; Dr. Fadzil Hamzah, from Sport Center of Changi General Hospital, Singapore and Dr. Deanne Helena Skelly, from Griffith University, Australia.

The aim of SIPS 2017 is to provide a platform for academicians, educators, researchers, practitioners, undergraduate and postgraduate students to share and discuss the knowledge of the recent issues, opinions, researchers about the development and innovation of physiology in medical science, dentistry, veterinary, plants and agriculture, sports and sciences.

I believe this event is a great purpose in order to develop knowledge, experiences and best practices that can be applied for the good, especially in the field of healthcare as a whole.

Finally, I would like to express my sincere acknowledgements to those who take part and especially for Department of Medical Physiology, Faculty of Medicine, Universitas Airlangga for their effort in holding this event and wishing all to have success.

Wassalamu'alaikum Wr. Wb.

Prof. Dr. Soetojo, MD.

Faculty of Medicine, Universitas Airlangga 


\section{Chair of Committee / Head of Physiology Department, Faculty of Medicine, Universitas}

Airlangga

Assalamu 'alaikum Wr. Wb

Greetings,

On behalf of SIPS committee and Physiology Department, Universitas Airlangga, we are welcoming to Surabaya, City of Heroes.

This year, the annual meeting of Indonesian Physiology Society (IAIFI) is hosted at Surabaya, entitled "Surabaya International Physiology Seminar Workshop (SIPS)". We present some update workshop and lectures in order to bring physiology research from basic to clinical application on humanities, animal welfare and good environment. All participants have opportunities to publish their research in presentation, poster and ISBN proceeding. Selected papers will be submitted to SCOPUS indexed proceeding/ journal and awarded as Best Poster and Best Oral Presentation.

We hope that all participants will get some interesting experiences for next 3 days, 12-14 October 2017. Enjoy our lectures and workshops, taste the culinary and take your time to sightseeing around Surabaya.

Wassalamu 'alaikum wr. wb.

Dr. Bambang Purwanto

Chairman of Committee / Head of Physiology Department

Faculty of Medicine, Universitas Airlangga 


\section{Welcome Address - Surabaya International Physiology Seminar Workshop (SIPS)}

Dear fellow Physiologists and Participants,

On Behalf of the Indonesian Physiological Society (IAIFI) and the Physiology Department Faculty of Medicine Universitas Airlangga, I would like to welcome you all to Surabaya International Physiology Seminar (SIPS), held on 12-14 of October 2017.

Finally after long-awaited Surabaya gets a turn again to host and organize the International Physiology Seminar. Hence the Steering- and Organizing Committee consisting of young energic physiologists are determined to make the Seminar a successful one. The theme of the seminar is:

"The Role of Physiology in Translation Research: From Basic to Application"

This annual meeting covers a wide range of topics of Physiology on Medicine, Dentistry, Veterinary, Plants and Agriculture, Sports and Sciences. We sincerely hope that SIPS 2017 enable to provide a platform for academicians, educators, researchers, practitioners and postgraduate students to present and discuss researches, development and innovations in wide range of topics as mentioned above. It will provide all participants to share knowledge, exchange new ideas and their experiences in many research topics, for then it will enhance future collaborations.

With great interest and enthusiasm I look towards the success of this Seminar, and wish all of you every success and a pleasant stay in Surabaya.

May Allah Swt. bestow upon us His Blessings.

On Behalf of the Steering and Organizing Committee Senior Physiologist,

Prof. R. Soedarso Djojonegoro 







\section{Contents}

\section{PAPERS}

\section{Full Papers}

The Dominant Personality Type in Vertigo Patients

Nanda Rizky FS, Netty Herawati, Nyilo Purnami, Nining Febriyana and Abdurachman

The Role of Osteocytes in Alveolar Bone During Tooth Movement Agni Febrina Pargaputril and Noengki Prameswari

Body Movement and Islamic Energy Psychology Acupressure to Improve the Future Orientation In A Person With HIV

Ambar Sulianti and Fenti Hikmawati

White Matter Changes in Neurodegenerative and Global Cortical Atrophy Scale Correlation in Older Patients Using Magnetic Resonance Imaging

Anggraini Dwi Sensusiati

The Influence of Mass Basic Life Support Training on The Skills and Attitude in Undertaking Life Support Using the Method of the Faculty of Medicine, Universitas Airlangga

Arie Utariani, Teguh Sylvaranto, April Poerwanto Basoeki, Prananda Surya Airlangga, Windy Ari Wijaya, Soni Sunarso Sulistiawan, Bambang Pujo Semedi, Christrijogo Sumartono, Hamzah, Kohar Hari Santoso, Philia Setiawan and Eddy Rahardjo

Reflections of a Physiology Teacher

Cheng Hwee Ming

Does Sequential Diabetes Dance Improve on Glucose Level and Glucose Tolerance?

Cynthia Wahyu Asrizal and Bambang Purwanto

Antioxidant Effect of Dayak Onion Extract (Eleutherine Americana Merr.) on Serum MDA Levels in Mice (Mus Musculus) Exposed by Lead Acetate

Daeng Agus Vieya Putri, Gadis Meinar Sari and Tjitra Wardani

Exercise as Cardiovascular Medicine: Early Detection and Optimal Prevention

Danny Green and Raden Argarini

The Effect of Circadian Rhythm on Hematopoietic Stem Cell Mobilization in Peripheral Blood as a Result of Submaximal Physical Exercise

Dhoni Akbar Ghozali, Harjanto and Agung Dwi Wahyu Widodo

The Effect of Intermitten Fasting Vs Low Calorie Diet to Insuline Like Growth Factor-1 (IGF-1) Concentration, Fat Mass and Lean Mass of Rattus Norvegicus Obesity Model

Dian Wijayanti, Sunarjati Sudigdo Adi, Achadiyani, Gaga Irawan Nugraha, Reni Farenia and Adi Santosa Maliki

Uphill $10^{\circ}$ Inclination Angle of Treadmill Concentric Exercises Improves Blood Glucose Levels and Glut-4 Levels in Diabetes Mice Model

Dini Surya Noviyanti, Bambang Purwanto and Choesnan Effendi 
Variability in The Response to Low Impact Aerobic Exercise in Women Abdominal Obese With the Polymorphism of Uncoupling Protein-1 Gene

D Mukhtar, Siagian M, N Ibrahim, Neng Tine, T Ahmad, M Suryaatmadja, SW Jusman, AS Sofro, $M$ Abdullah, S Waspadji and S Sugondo

The Effect of an Aluminium Foil Shield on Reducing The Strength of Electromagnetic Radiation of Mobile Phones Reaching the Oculi of Adult Male Rats

Dion K. Dharmawan, Viskasari P. Kalanjati and Abdurachman

The Effect of Osteocyte Signalling on Osteocyte Apoptosis

Dwi Setiani Sumardiko, Purwo Sri Rejeki and Gadis Meinar Sari

Intermittent Physical Training Decreases Peak of Blood Glucose Level after Meals in Rats

Eka Arum Cahyaning Putri, Raden Argarini, Bambang Purwanto and Lilik Herawati

The Effect of Cantaloupe Extract on Sperm Quality of Adult White Rats (Rattus Novergicus) Strain Induced by Ciproteron Acetat

Elyna Mahruzza Putri, Achadiyani, Sunarjati, Sudigdoadi, Oki Suwarsa and Adi Santosa Maliki

Correlation Between Academic Stress, Sleep Quality, Circadian Misalignment, Cortisol Concentration and Heart Rate Value at the First Year Medical Student at the State Islamic University Maulana Malik Ibrahim of Malang

Ermin Rachmawati, Muhammad Farid Wafi and Ira Resmi Melani

PIGF as Predictor of Preeclampsia Complication

Ernawati E, Manggala PS, Khanisyah Erza, Rozi Aditya, Cininta M, MI Aldika Akbar, Budi Wicaksono, Agus Sulistyono, Hermanto TJ, Nadir Abdulah, Erry Gumilar and Adityawarman A

Aluminum Foil Shield Diminishes the Electromagnetic Radiation of Mobile Phones in the Cerebellum of Adult Male Rats

Etha Rambung, Viskasari P. Kalanjati and Abdurachman

Sauropus Androgynus for Increasing Uterine Weight in Menopausal Women: An Experimental Study

Using Animal Models

Exma Mu'tatal Hikmah and Retno Susilowati

Exercise And Swimming in Pregnancy - Physiological Considerations

Fadzil Hamzah

The Comparison Effect Between Bodyweight and Sprint Interval Exercises Using Tabata Method Towards Heart Rate Frequency, Lactate Blood and Physical Fatigue Perception Fengki Aditiansyah, Elyana Asnar and Choesnan Effendi

Detection of $\mathrm{COMT}^{\mathrm{Val}} 158^{\text {Met }}$ Gene Polymorphism in Chronic Schizophrenic Patients at Psychiatric Unit of DR. Soetomo Hospital Surabaya, East Java, Indonesia

Gwenny Ichsan Prabowo, Margarita Maria Maramis, Erikavitri Yulianti, Afrina Zulaikah,

Zain Budi Syulthoni, Citrawati Dyah Kencono Wungu, Hendy Muagiri Margono and Retno Handajani

Hyperbaric Oxygen (HBO) Heals Cell Through Reactive Oxygen Species (ROS)

Handi Suyono and Guritno Suryokusumo

Correlation of Fat Free Mass and Skeletal Muscle Mass with Left Ventricular Mass in Indonesian Elite Wrestlers and Dragon Boat Rowers

Henny Tantono, Mohammad Rizki Akbar, Badai B. Tiksnadi, Triwedya Indra Dewi, Sylvie Sakasasmita, 128 Maryam Jamilah, Daniel Womsiwor, Ambrosius Purba, Augustine Purnomowati and Toni Mustahsani Aprami 
Decrease of Homocysteine Plasma Degree in Smokers by Low Intensity Weight Training and Supplementation of Folic Acid and Cyanocobalamin

HS Muhammad Nurfatony, Damayanti Tinduh and Tjitra Wardhani

The Role of Physiology in Ergonomics - Empowerment Human Resources for Nations Competitiveness

I Putu Gede Adiatmika

Influence of Use of Insole on Blood Glucose Rate Diabetes Mellitus Type-2

Ignatius Heri Dwianto, Bambang Purwanto and Sony Wibisono

The Profile of Endothelin-1 (Et-1), Receptor $\mathrm{ET}_{\mathrm{A}}$, And Receptor $\mathrm{ET}_{\mathrm{B}}$ in Young and Adult Obese

Wistar Rat

Irfan Idris, Aryadi Arsyad, A. Wardihan Sinrang and Syarifuddin Alwi

Characteristics of Glucose Tolerance, Energy Expenditure, Lactic Acid Level, and Oxygen Saturation in Indonesian Diabetes Dance Version 6

Irfiansyah Irwadi and Bambang Purwanto

The Effect of Aluminium Foil Shielding in Hampering Electromagnetic Radiation Emitted from A

Mobile Phone as an Oxidative Stressor in The Cerebra of Adult Male Rats

Irmawan Farindra, Viskasari P. Kalanjati and Ni Wajan Tirthaningsih

Effect of Exercise on Learning Capability and Memory of Mice (Mus Musculus) Exposed to Monosodium Glutamate (MSG)

Husnur Rofiqoh, Kristanti Wanito Wigati and Suhartati

Low, Moderate, and High Intensity Swimming Exercise Has No Negative Effect on Semen Analysis

Test in Male Wistar Rats

Kristanti Wanito Wigati, Sundari Indah Wiyasihati and Misbakhul Munir

High-Calorie Diet Reduces Neuroglia Count

Nilam Anggraeni, Kristanti Wanito Wigati, I Lukitra Wardani and Lilik Herawati

Three Weeks of High-Intensity Interval Training (HIIT) Decreases Visfatin Level on Overweight Men

Amal A. Hidayat, Mohammad Budiarto and Lilik Herawati

VO2MAX of Ergocycle Astrand Test Differs from 12-Minutes Cooper Running Test on Medical

Students' Physical Fitness Level

Bella Anggi Afisha, Atika and Lilik Herawati

Non-Invasive Method on Slow-Twitch Quadriceps Muscle Fibers Dominate a High Level of Fitness Yuannita Ika Putri, Andre Triadi Desnantyo and Lilik Herawati

Genotype Hepatitis B Virus Among Intravenous Drug Users with Occult Hepatitis B Infection in Surabaya, Indonesia

Lina Lukitasari, Lilik Herawati, Edhi Rianto, Indri Safitri, Retno Handajani and Soetjpto

Anopheles Vagus Larval Midgut Damage as an Effect of Areca Catechu L. Seed Extract Majematang Mading, Yeni Puji Lestari, Etik Ainun Rohmah, Budi Utomo, Heny Arwati and 192 Subagyo Yotopranoto

The Effect of Mozart's Music on Mus Musculus Balb/C Spermatozoa's Quantity and Motility Exposed by Lead Acetate

Maria Selviana Joni, Paulus Liben and Hermanto Tri Joewono 
The Lactid Acid's Decrease After Submaximal Exercise Due to Zamzam Water Treatment Compared the Packed Water

Moh. Tomy Yusep, Elyana Asnar STP and Harlina

The Correlation of Lung Vital Capacity, $\mathrm{VO}_{2} \mathrm{Max}$, and Heart Rate Recovery With Changes in Blood Lactate Levels in Young Male: Cross Sectional Study in Provoked By Repeated Sprint Sessional-3

Mustofa, Susiana Candrawati, Khusnul Muflikhah, Tiara Dwivantari, Rahardita Alidris and 204 Dessy Dwi Zahrina

Fgf 21 Secretion as Acute Response to Exercise in High Fat Diet Fed Rats

Nafi'ah, Imelda Rosalyn Sianipar, Nurul Paramita, Rabia and Neng Tine Kartinah

The Miracle of Stichopus Hermanii

Noengki Prameswari

Effect of Chemical Exposure on Endocrine System Disorder (Article Review)

Nurul Mahmudati and Husamah

The Effect of Acute Exercise of Basic Breathing Motion on Breathing Skills Retention in Swimming Okky Sinta Dewanti and Choesnan Effendi

Correlation Between Body Mass Index and Medial Longitudinal Arch of The Foot in Children Aged 5-6 Years

Purwo Sri Rejeki, Irfiansyah Irwadi, Widiarti and Misbakhul Munir

Correlation Between Agility and Flat Feet in Children 5-6 Years Old

Anita Faradilla Rahim, Miftahul Nur Amaliyah, Irfiansyah Irwadi and Purwo Sri Rejeki

Correlation Between Hand Grip and Achievement in Indonesian Female Floorball Athletes

Loren Fibrilia Perangin-angin, Siti Maesaroh, Irfiansyah Irwadi and Purwo Sri Rejeki

Maternal Anthropometrics as a Predictor of Preeclampsia Risk Factor

Putri Wulan Akbar, Florentina Sustini, Hermanto Tri Juwono and Handayani

Correlation Between Activity Level and Circadian Rhythmicity of Medical Students (Class Of 2014)

at the Faculty of Medicine, Airlangga University

Qurrota Ayuni Novia Putri, Irfiansyah Irwadi, Agustina Salinding and Sundari Indah Wiyasihati

Exercise Formula to Induce Beiging Process: A Study Based on Acute Response of Irisin

Rabia, Neng Tine Kartinah, Nurul Paramita, Nafi'ah and Imelda Rosalyn Sianipar

Effects of the 6th Series of Senam Diabetes Indonesia on Energy Expenditure

Riza Pahlawi, Harjanto JM and Dwikora Novembri Utomo

The Difference of B-Endorfin Level in Brain Tissue and Testicular Tissue on Wistar Rats Given Once

a Week Aerobic and Anaerobic Exercise

Rostika Flora, Lisna Ferta Sari, Muhammad Zulkarnain and Sukirno

The Effectiveness of Ultrasound-Guided Injection for Pain Management in Indonesia Soni Sunarso Sulistiawan, Dedi Susila, Belindo Wirabuana, Herdiani Sulilstyo Putri, Yusufa Fil Ardy, Ferdian Rizaliansyah, Noryanto Ikhromi, Bambang Pujo Semedi, Arie Utariani, Hamzah and Nancy Margarita Rehatta

Effects of Moderate Intensity Aerobic Exercise on MMP-9 Level, NOx Plasma Level and Resting Blood Pressure in Sedentary Elderly Women With Overweight

Suhartini SM, Gusbakti R and Ilyas EII 
Correlation Between Oxidative Stress Level with Plasma Beta Endorphin Level of Male Laboratory

Rats Given Aerobic and Anaerobic Exercise

Sukirno, Herlia Elvita, Mohammad Zulkarnain and Rostika Flora

Bone Age Estimates the Onset of the Adolescent Growth Spurt Among Male Basketball Players Sundari Indah Wiyasihati, Bambang Purwanto and Agus Hariyanto

The Correlation Between Haemoglobine and Body Mass Index With The Changes of Blood Lactate Levels in University of Jenderal Soedirman's Medical Students - A Study at Repeated Sprint Sessional 3

Susiana Candrawati, Wiwiek Fatchurohmah, Ahmad Agus Faisal and Hana Khairunnisa

Laughter Therapy Lowers Blood Pressure and Heart Rate in Hypertensive Balinese Patients at Ambarashram Ubud Bali

Suyasning HI and Adi Pratama Putra P

The Different Effects of Contrast Water Immersion and Warm Water Immersion on Blood Lactic Acid Levels After Submaximal Physical Activity Among Basketball Athletes

Taufan Reza Putra, Elyana Asnar STP and Dwikora Novembri

Diabetes Sprague-Dawley Model Induced With Fat Diet And Streptozotocin

Thressia Hendrawan, Nurul Paramita, Dewi Irawati and Ani Retno Prijanti

The Difference of Heart Rate and Blood Pressure in Aerobic and Anaerobic Predominant Athlete Koni

West Java Year 2016

Titing Nurhayati, Hafiz Aziz and Nova Sylviana

Effect of Exhaustive Exercise on Blood Lymphocyte Count and Diameter of Splenic White Pulp in

Rats

Tri Hartini Yuliawati, Dewi Ratna Sari, Rimbun, Atika, Iskantijah and Ari Gunawan

The Use of Purple Sweet Potato (Ipomoea Batatas L.) to Decrease Levels of Mda and Recover Muscle

Damage

Utami Sasmita Lestari, Elyana Asnar and Suhartati Soewono

Risk Factors of Low Back Pain Among Tailors in Kramat Jati, East Jakarta

Vivi Anisa Putri, Leli Hesti and Nurfitri Bustamam

The Correlation of Norovirus Infection to Severity Degree of Acute Diarrhea in Children Under Five

Years Old in Mataram City, Lombok

Warda Elmaida, Juniastuti and Soetjipto

Malaria Prevalence in Alor District, East Nusa Tenggara, Indonesia

Yeni Puji Lestari, Majematang Mading, Fitriah, Avia Putriati Martha, Didik Muhammad Muhdi, 321

Juniarsih, Zainal Ilyas Nampira, Sukmawati Basuki and Florentina Sustini

The Potential Role of 25-Hydroxycholecalciferol on Calcium Regulation in Young Sedentary Women

With Goat's Milk Intervention

Yusni

Hemoglobin A1C as the Strongest Influencing Factor in relation to Vascular Stiffness in Type 2

Diabetes Mellitus - Metabolic Syndrome Patients

Deasy Ardiany, Soebagijo Adi, Ari Sutjahjo and Askandar Tjokroprawiro

Thyroid Crisis and Hyperosmolar Hyperglycemic State in a Hyperthyroid Patient Yudith Annisa Ayu Reskitha, Rio Wironegoro, Hermawan Susanto, Soebagijo Adi and Ari Sutjahjo 
Effect of Growth Hormone Deficiency on the Cardiovascular System

Irma Magfirah, Soebagijo Adi Soelistijo, Hermina Novida and Deasy Ardiany

Metformin, Effects Beyond Glycemic Control

Soebagijo Adi Soelistijo and Askandar Tjokroprawiro

The Correlation of Initial CD4 Cell Count with Increased Alanine Aminotransferase in Patients with

Human Immunodeficiency Virus Who Have Received Nevirapine

Abdur Rokhim, Usman Hadi and Erwin Astha Triyono

Profile of Bacteraemia and Fungemia in HIV/AIDS Patients with Sepsis

Sajuni Widjaja, Erwin Astha Triyono and Arthur Pohan Kawilarang

The Association between Cryptococcal Antigenemia and CD4+ T lymphocyte Count in HIV/AIDS

Patients with Suspected Cryptococcus Infection

Sajuni Widjaja, Erwin Astha Triyono and Arthur Pohan Kawilarang

Impact of Music on Sport Intensity (Allegro) and on Levels of Left Ventricular Myocardial Damage in Wistar Rats

Faris Pamungkas Wicaksono, Sugiharto, Rias Gesang Kinanti, Paulus Liben, Suhartono Taat Putra and Purwo Sri Rejeki

Association of Topical Capsaicin Exposure Dosage and Its Influence on Macrophages and Neutrophils in Periodontal Tissue

Ratna Mustriana, Haryono Utomo and Purwo Sri Rejeki

Pharmacological Therapy of Portal Hypertension

Mukhammad Burhanudin, Iswan Abbas Nusi, Poernomo Boedi Setiawan, Herry Purbayu,

Titong Sugihartono, Ummi Maimunah, Ulfa Kholili, Budi Widodo, Muhammad Miftahussurur,

Husin Thamrin and Amie Vidyani

Chronic Constipation Management in Adults

Erliza Fatmawati, Iswan Abbas Nusi, Poernomo Boedi Setiawan, Herry Purbayu, Titong Sugihartono, Ummi Maimunah, Ulfa Kholili, Budi Widodo, Husin Thamrin, Amie Vidyani and Muhammad Miftahussurur

Diagnosis and Management of Ulcerative Colitis

Rendy Revandana Bramantya, Iswan Abbas Nusi, Poernomo Boedi Setiawan, Herry Purbayu, Titong Sugihartono, Ummi Maimunah, Ulfa Kholili, Budi Widodo, Amie Vidyani, Muhammad Miftahussurur and Husin Thamrin

The Diagnosis and Management of Achlorhydria

Dicky Febrianto, Iswan Abbas Nusi, Poernomo Boedi Setiawan, Herry Purbayu, Titong Sugihartono,

Ummi Maimunah, Ulfa Kholili, Budi Widodo, Amie Vidyani, Muhammad Miftahussurur and

Husin Thamrin

Acute Liver Failure

Troy Fonda, Iswan Abbas Nusi, Poernomo Boedi Setiawan, Herry Purbayu, Titong Sugihartono,

Ummi Maimunah, Ulfa Kholili, Budi Widodo, Husin Thamrin, Amie Vidyani and 421

Muhammad Miftahussurur

Transient Elastography as Non-Invasive Examination of Hepatic Fibrosis

Satyadi, Iswan Abbas Nusi, Poernomo Boedi Setiawan, Herry Purbayu, Titong Sugihartono,

Ummi Maimunah, Ulfa Kholili, Budi Widodo, Amie Vidyani, Muhammad Miftahussurur and

Husin Thamrin

XVI 
Termination of Antiviral Administration in Chronic Hepatitis B

Edward Muliawan Putera, Iswan Abbas Nusi, Poernomo Boedi Setiawan, Herry Purbayu,

Titong Sugihartono, Ummi Maimunah, Ulfa Kholili, Budi Widodo, Husin Thamrin, Amie Vidyani and 431

Muhammad Miftahussurur

Management for a Patient with Barret's Esophagus: A Case Report

Muhammad Miftahussurur, Iswan Abbas Nusi, Poernomo Boedi Setiawan, Herry Purbayu, 438

Titong Sugihartono, Ummi Maimunah, Ulfa Kholili, Budi Widodo, Husin Thamrin and Amie Vidyani

Thrombocytopenia in Chronic Hepatitis C

Arvi Dian Prasetia Nurwidda, Poernomo Boedi Setiawan, Iswan Abbas Nusi, Herry Purbayu,

Titong Sugihartono, Ummi Maimunah, Ulfa Kholili, Budi Widodo, Amie Vidyani,

Muhammad Miftahussurur and Husin Thamrin

Short Bowel Syndrome: Review of Treatment Options

Nina Oktavia Marfu'ah, Herry Purbayu, Iswan Abbas Nusi, Poernomo Boedi Setiawan,

Titong Sugihartono, Ummi Maimunah, Ulfa Kholili, Budi Widodo, Muhammad Miftahussurur,

Husin Thamrin and Amie Vidyani

Problematic Diagnosis of a Patient with Tuberculosis Peritonitis

Elieza L. Pramugaria, Iswan Abbas Nusi, Poernomo Boedi Setiawan, Herry Purbayu,

Titong Sugihartono, Ummi Maimunah, Ulfa Kholili, Budi Widodo, Husin Thamrin, Amie Vidyani and

Muhammad Miftahussurur

Pathophysiology of Irritable Bowel Syndrome

Rastita Widyasari, Iswan Abbas Nusi, Poernomo Boedi Setiawan, Herry Purbayu,

Titong Sugihartono, Ummi Maimunah, Ulfa Kholili, Budi Widodo, Husin Thamrin, Amie Vidyani and

Muhammad Miftahussurur

Recent Pathophysiology and Therapy for Paralytic Ileus

I Putu Surya Pridanta, Ulfa Kholili, Iswan Abbas Nusi, Poernomo Boedi Setiawan, Herry Purbayu,

Titong Sugihartono, Ummi Maimunah, Budi Widodo, Amie Vidyani, Muhammad Miftahussurur and

Husin Thamrin

A Case Report of a Patient with a Rare and Aggressive Plasma Cell Leukemia

Ugroseno Yudho Bintoro, Putu Niken Amrita, Raharjo Budiono, Made Putra Sadana and 482 Ami Ashariati

Decreased Triglyceride and Protein Levels in Diabetic Rat Muscle Following Physical Exercise

Susi Anggawati, Bambang Purwanto and Sutji Kuswarini

Abnormal Uterine Bleeding with Three Different Doses and Intervals of Hormonal Contraceptive Injection

Ananda Febina Kimresti A, Ashon Sa'adi, Lilik Djuari and Maftuhah Rochmanti

Hypertrophic Scars Cause Burn Injuries Assessed by the Vancouver Scar Scale

Ardea Ramadhanti Perdanakusuma, Iswinarno Doso Saputro and Diah Mira Indramaya

Description of Body Mass Index Changes in Emergency Patients at the Intensive Observation

Room-Emergency Installation

Galang Damariski Lusandi, Prananda Surya Airlangga and Ariandi Setiawan

Laboratory Profile of Acute Diarrhea and Chronic Diarrhea in Children

Mochammad Nasrulloh, Alpha Fardah Athiyyah and Arifoel Hajat 
Effect of Ethanol Extract of Ruellia tuberosa L. Leaves on Total Cholesterol Levels in Hypercholesterolemia Model of Mus Musculus L

Nurin Kusuma Dewi, Siti Khaerunnisa and Danti Nur Indriastuti

Combination of Aerobic and Resistance Exercise in Lowering Blood Glucose Levels Compared to Aerobic or Resistance Exercises in a Male Wistar Rat Model with Diabetes Mellitus

Sahrul Latif, Dwikora Novembri Utomo and Purwo Sri Rejeki

AUTHOR INDEX 


\title{
Does Sequential Diabetes Dance Improve on Glucose Level and Glucose Tolerance?
}

\author{
Cynthia Wahyu Asrizal ${ }^{1,3}$ and Bambang Purwanto ${ }^{2}$ \\ ${ }^{I}$ Master's Student in Basic Medical Science of Physiology \\ ${ }^{2}$ Department of Physiology, Faculty of Medicine, Airlangga University, Campus A Jl. Mayjen Prof. Moestopo 47, \\ Surabaya, Indonesia \\ ${ }^{3}$ Department of Physiology, Faculty of Medicine, Syiah Kuala University, Jl. Tgk Tanooh Abee, Banda Aceh, Indonesia \\ bpaifo@gmail.com
}

Keywords: Diabetes, Diabetes Dance, Eccentric, Glucose Level, GLUT.

Abstract: $\quad$ Repeated exercise can improve uptake of glucose, glucose tolerance, and insulin sensitivity in muscles more than a single bout. The eccentric contraction can also improve glucose tolerance by increasing GLUT 4 as well as insulin-stimulated muscle glucose uptake after exercise.This study aimed to investigate whether the sequential diabetes dance can improve glucose tolerance and postprandial glucose levels. We performed the diabetes dance three times a week with female non-diabetic or healthy subjects. Before and after performing the diabetes dance, we analyzed the fasting glucose level and postprandial glucose level. The postprandial glucose level, but not the fasting glucose level, was significantly lower after the sequential (three times a week) diabetes dance performances $(\mathrm{p}=0.039)$. Sequential diabetes dance improved postprandial glucose levels and glucose tolerance.

\section{INTRODUCTION}

Hyperglycemia is a glucose metabolism disorder in peripheral tissues such as the skeletal muscle, adipose and liver. It was resulted from low level of insulin secretion and response to stimulate glucose uptake (Guyton et al., 2014; Perkeni, 2015; ADA 2017). This condition is caused by genetic and lifestyle disorders such as lack of physical activity, poor eating habits, and obesity, which creates insulin resistance (Hamilton, Hamilton and Zderic, 2015; Perkeni, 2015; ADA, 2017). A meta-analysis stated that sedentary people had an $112 \%$ increased risk of impaired glucose metabolism and type 2 diabetes mellitus (Wilmot et al., 2012).

The current exercise studies and guidelines recommend that aerobic-type exercise at moderate and/or vigorous-intensity exercise is undertaken three to five days per week corresponding to 50 $70 \%$ of maximal heart frequency. This is one of the important methods to improve uptake of glucose and glucose tolerance, and as a prevention and treatment of type 2 diabetes mellitus (Colberg et al., 2010; Perkeni, 2015; Röhling et al., 2016; ADA, 2017). Previous studies have suggested that eccentric exercise also improve glucose levels. Eccentric exercise increases basal glucose levels acutely, due to the synthesis of glucose transporters. The glucose transporters stimulates glucose uptake after exercise (Purwanto et al., 2013).

The current literature also states that repeated exercise can improve the glucose metabolism more than a single bout because of a dose-response relationship. Repeated exercise regulates more in metabolic improvements like insulin sensitivity, transcription and expression of GLUT4 (Lehnen, 2012; Richter and Hargreaves, 2013; Röhling et al., 2016).

The diabetes dance is a dance that uses a combination of aerobic exercise and eccentric movements that are expected to improve uptake of glucose and glucose tolerance. The sequential diabetes dance was considered to be able to prevent glucose level impairment on pre diabetic subject. This experiment aimed to ascertain if the repeated diabetes dance would improve glucose tolerance and postprandial glucose levels. 


\section{METHODS}

\subsection{Study Participants}

Nine female non-diabetic or healthy subjects, graduate students of the medical faculty of Airlangga University, were recruited to participate in this study. The subjects had to meet the criteria: female, healthy, sedentary (fewer than 2.0 hours of physical exercise per week), non-smoker, no history of acute or chronic diseases that would complicate a good performance. The exclusion criteria were: subject with diabetes mellitus type 2 or diabetes mellitus type 1 . Informed consent was provided by every participant. Characteristics of the study participants are shown in Table 1.

Table 1: Characteristics of study participants $(\mathrm{N}=9)$.

\begin{tabular}{|c|c|}
\hline Characteristic & Mean \pm SD \\
\hline Age (years) & $25.78 \pm 3.3$ \\
\hline Height (m) & $1.58 \pm 3.24$ \\
\hline Body mass (kg) & $56.2 \pm 9.9$ \\
\hline BMI (kg m-2) & $22.4 \pm 4$. \\
\hline Energy expenditure (kkal) & $98.56 \pm 33.03$ \\
\hline \% of max HR (\%) & $63.9 \pm 7.11$ \\
\hline
\end{tabular}

\subsection{Study Protocol}

This study was designed with experimental pre and post test models. The experiment was completed within eight days. All participants underwent a fasting glucose level and postprandial glucose level beforehand (day 1) and again after the diabetes dance intervention (day 8). The subject performed the diabetes dance three times a week, on the first day, the third day and the fifth day in one week. Post test was measured 72 hours after the last bout of exercise. An outline of the experimental time schedule appears in Figure 1.

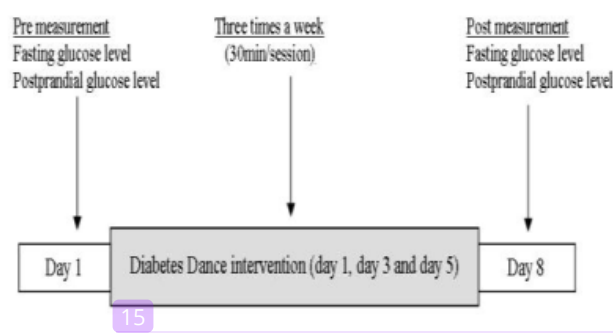

Figure 1: Study overview of the experiment prior to and after the diabetes dance intervention.

\subsection{Diabetes Dance Intervention}

Participants performed diabetes dance for 30 minutes per session three times a week, on Monday, Wednesday and Friday. They followed the dance movement from the video after previously being given an explanation about the movement. Each participant must complete all sessions.

\subsection{Measurement of Glucose Level}

A fasting glucose level and postprandial glucose level was measured and analyzed using an Easy Touch glucose check unit (MHC Medical Products, LLC, Taiwan). The participants attended for premeasurement on the first day after a minimum 8hour overnight fast. After we measured the fasting glucose level, participants had to eat $350 \mathrm{kkal}$ of food. Participants waited 2 hours for the next examination, and participants were not allowed to eat anything in that time. Two hours after ingestion we measured again the postprandial glucose level. The same measurement procedure was repeated again after the diabetes dance intervention on the eighth day.

\subsection{Measurement of Energy Expenditure}

Energy expenditure was measured using Actiheart. Actiheart is a device that was attached to the chest wall while the participants performed the diabetes dance. Afterwards the results were read on the available application.

\section{RESULT}

Following the three-times-a-week diabetes dance, the postprandial glucose level had significantly changed $(\mathrm{p}=0.039)$. The fasting glucose level did not significantly change $(\mathrm{p}=0.615)$ as a result of the intervention. However, there is potential for improvement because the mean of the level of fasting glucose decreased after the intervention from $86.11 \pm 7.46$ into $84.56 \pm 7.7$. The results of this study are shown in Table 2, Figure 2. 
Table 2: The comparison of fasting glucose level and postprandial glucose level pre and post diabetes dance intervention.

\begin{tabular}{cccc}
\hline $\begin{array}{c}\text { Glucose } \\
\text { level }\end{array}$ & $\begin{array}{c}\text { Pre } \\
(\mathrm{mg} / \mathrm{dl})\end{array}$ & $\begin{array}{c}\text { Post } \\
(\mathrm{mg} / \mathrm{dl})\end{array}$ & $\begin{array}{c}\text { Paired } \\
\text { T-test } \\
\mathrm{P}\end{array}$ \\
\hline $\begin{array}{c}\text { Fasting } \\
\text { Post }\end{array}$ & $86.11 \pm 7.46$ & $84.56 \pm 7.7$ & 0.615 \\
prandial & $104.2 \pm 11.5$ & $97.3 \pm 13.9$ & $0.039^{*}$ \\
\hline *p <0.05 & indicating significant & difference in \\
postprandial \\
intervention
\end{tabular}

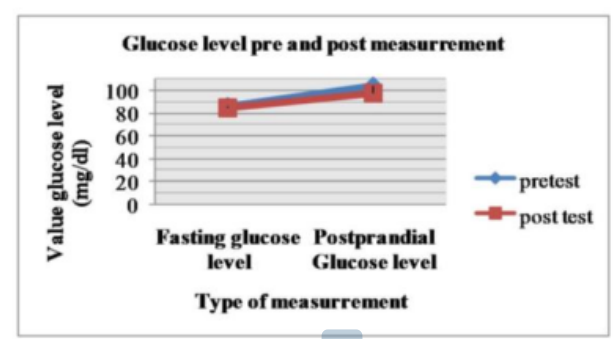

Figure 2: The graphic of fasting glucose level and postprandial glucose level pre and post measurement. There is a decrease in the extent of the graphs on postmeasurement after intervention.

\section{DISCUSSION}

The main finding of this study was, the improvent of postprandial glucose level after diabetes dance sequencial performance. Our result supported previous finding that repeated exercise significantly increase on insulin sensitivity between 48 to 72 hours after exercise (Way et al., 2016).

There are different mechanisms of insulin mediated-glucose uptake levels, as the chronic effects of exercise. Improvement on blood flow expands the delivery area of glucose and insulin, change in GLUT4 transcription factors, resulting in an increase in intracellular GLUT4 stores, and change in protein endocytosis and exocytosis. Exercise also improves insulin action, with increased expression and activity of the insulin-signaling protein kinase (Lehnen, 2012).

Previous studies stated that contraction of the muscle results in greater TBC1D1 phosphorylation, which is likely to be secondary to increased AMPactivated protein kinase (AMPK) activity and potentially important for contraction-stimulated glucose uptake and insulin-stimulated glucose uptake (Richter and Hargreaves, 2013; Cartee,
2015). GLUT4 expression is regulated through AMPK and CaMKII pathway with HDAC4/5-MEF2 axis and MEF2-GEF interactions resulting in histone hyperacetylation on the GLUT4 promoter and increased GLUT4 transcription resulting in more intracellular GLUT4 stores (Richter and Hargreaves, 2013).

Second, fasting glucose levels did not change significantly after the intervention. Our findings were consistent with Purwanto's study (Purwanto et al., 2013); the fasting glucose level raised again on the third day. The eccentric movement of the diabetes dance activates p38MAPK and GLUT1 expression to improves basal glucose uptake. The improvement of GLUT1 reduces insulin dependence, and improves glucose uptake with GLUT4 (Purwanto et al., 2013).

In this study, the fasting glucose level pre and post is $86.11 \pm 7.46$ and $84.56 \pm 7.7$. There are various compensation mechanisms to maintain blood glucose levels within normal range conditions so it does not become hypoglycemic, such as halting insulin secretion if the blood glucose level reaches $80 \mathrm{mg} / \mathrm{dl}$, starting the secretion of the glucagon hormone, epinephrine, growth hormone, and cortisol when blood glucose levels reach $70 \mathrm{mg} / \mathrm{dl}$ to increase gluconeogenesis (Guyton et al., 2014; Barrett et al., 2016).

\section{CONCLUSIONS}

The diabetes dance significantly improves glucose tolerance and insulin-stimulated glucose uptake, but not basal glucose uptake. These findings also demonstrate that the diabetes dance is a beneficial exercise strategy in prevention and treatment of T2D patients. The diabetes dance should be done regularly to prevent insulin resistance.

\section{REFERENCES}

ADA (2017), The Journal OF CIINICAL AND APPLIED RESEARCH AND EDUATION, 40(American diabetes Association Standars of Medial care In Diabetes2017).

Barrett, K. E. et al. (2016) Ganong's Review of Medical Physiology.

Cartee, G. D. (2015) 'Roles of TBC1D1 and TBC1D4 in insulin- and exercise-stimulated glucose transport of skeletal muscle', Diabetologia, 58(1), pp. 19-30. doi: 10.1007/s00125-014-3395-5.

Colberg, S. R. et al. (2010) 'Exercise and type 2 diabetes: The American College Of Sports Medicine and The 
American Diabetes Association: Joint position statement executive summary', Diabetes Care, 33(12), pp. 2692-2696. doi: $10.2337 / \mathrm{dc} 10-1548$.

Guyton, L. et al. (2014) Guyton and Hall Textbook of Medical Physiology, Igarss 2014. doi: 10.1007/s 13398-014-0173-7.2.

Hamilton, M. T., Hamilton, D. G. and Zderic, T. W. (2015) 'Sedentary behavior as a mediator of type 2 diabetes', Med Sport Sci, (225), pp.1126.doi:10.1159/000357332.Sedentary.

Lehnen (2012) 'Changes in the GLUT4 Expression by Acute Exercise, Exercise Training and Detraining in Experimental Models', J Diabetes Metab, (10). doi: 10.4172/2155-6156.S10-002.

Perkeni (2015) Konsensus Pengelolaan dan Pencegahan Diabetes Melitus tipe 2 di Indonesia 2015, Pengurus Besar Perkumpulan Endokrinologi Indonesia (PB Perkeni).doi:10.1017/CBO9781107415324004.

Purwanto, B. et al. (2013) 'Muscle Glucose Transporter 1 ( Glut-1 ) Expression in Diabetic Rat Models', FOlia Medica Indonesia, 49, pp. 21-25.

Richter, E. a and Hargreaves, M. (2013) 'Exercise, GLUT4, and skeletal muscle glucose uptake.', Physiological reviews 93(3),pp.9931017.doi: 10.1152/physrev.00038.2012.

Röhling, M. et al. (2016) 'Influence of Acute and Chronic Exercise on Glucose Uptake', Journal of Diabetes Research. Hindawi, 2016 pp. 1-33. doi: $10.1155 / 2016 / 2868652$.

Way, K. L. et al. (2016) 'The Effect of Regular Exercise on Insulin Sensitivity in Type 2 Diabetes Mellitus: A Systematic Review and Meta-Analysis.', Diabetes \& metabolism journal. Korean Diabetes Association, 40(4), pp.253-71.doi: $10.4093 / \mathrm{dmj} .2016 .40 .4 .253$

Wilmot, E. G. et al. (2012) 'Sedentary time in adults and the association with diabetes, cardiovascular disease and death: Systematic review and meta-analysis', Diabetologia, 55(11), pp. 2895-2905. doi: $10.1007 / \mathrm{s} 00125-012-2677-\mathrm{z}$ 
Does Sequential Diabetes Dance Improve on Glucose Level and Glucose Tolerance?

ORIGINALITY REPORT



SIMILARITY INDEX

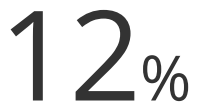

INTERNET SOURCES
$5 \%$

PUBLICATIONS
O\%

STUDENT PAPERS

PRIMARY SOURCES

1 repository.uin-malang.ac.id

Internet Source

2 sintadev.ristekdikti.go.id

3 fk.unjani.ac.id

4 fsd.unsyiah.ac.id Internet Source

5 repository.ikopin.ac.id Internet Source

6 Www.omicsonline.org Internet Source

7 link.springer.com 
10 prosiding.respati.ac.id

11 repository.unsri.ac.id

Internet Source

12 www.longdom.org

Internet Source

13 nexs.ku.dk

Internet Source

14 Ching-Yu Chou. "Pregnancy Outcome of Women Whose Oral Glucose Test Met the

Carpenter-Coustan Criteria but Not the

National Diabetes Data Group Criteria in a

Taiwanese Population", Journal of Women s

Health, 04/06/2010

Publication

15

Søren Møller Madsen, Anne Cathrine Thorup,

Kristian Overgaard, Per Bendix Jeppesen.

"High Intensity Interval Training Improves

Glycaemic Control and Pancreatic $\beta$ Cell

Function of Type 2 Diabetes Patients", PLOS

ONE, 2015

Publication

16 repository.unhas.ac.id Internet Source 
18 www.asean-endocrinejournal.org

19 zenodo.org

20 S. K. Paul, R. R. Holman. "Do glycoalbumin levels preferentially reflect changes in postprandial glucose excursions?", Diabetic Medicine, 2017

Publication

21 siladikti.hangtuah.ac.id Internet Source

22 Keyvan Hejazi, Seyyed Reza Attarzadeh Hosseini, Mehrdad Fathi, Mohammad Mosaferi Ziaaldini. "Responses of Visfatin and Resistin Concentration to Different Aerobic Training Intensities Protocols", Annals of Military and Health Sciences Research, 2020 Publication

"Abstracts", Diabetologia, 2005

25 e-journal.unair.ac.id 
27 Joungmok Kim, Goowon Yang, Joohun Ha.

"Targeting of AMP-activated protein kinase: prospects for computer-aided drug design",

Expert Opinion on Drug Discovery, 2016

Publication

28

biblio.ugent.be

Internet Source

29 "1-B2: Respiratory Infections (Non-

Tuberculosis) 2 : Poster Sessions",

Respirology, 2013.

Publication

30

Ashley G. Ambery, Lixuan Tackett, Brent A.

Penque, Joseph T. Brozinick, Jeffrey S.

Elmendorf. "Exercise training prevents

skeletal muscle plasma membrane

cholesterol accumulation, cortical actin

filament loss, and insulin resistance in

C57BL/6J mice fed a western - style high - fat

diet", Physiological Reports, 2017

Publication

31 etd.repository.ugm.ac.id

Internet Source

$<1 \%$

32 journals.plos.org

Internet Source 
Erna Febriyanti, Febtian Cendradevi Nugroho, Analizza Ina Lea. "Predictors of Glycemic Control in Type II Diabetes Mellitus Patients", KnE Life Sciences, 2022

"Poster Presentation", Journal of Diabetes Investigation, 2012.

Ranganath Muniyappa, Sihoon Lee, Hui Chen, Michael J. Quon. "Current approaches for assessing insulin sensitivity and resistance in vivo: advantages, limitations, and appropriate usage", American Journal of PhysiologyEndocrinology and Metabolism, 2008 Publication 


\section{Does Sequential Diabetes Dance Improve on Glucose Level and Glucose Tolerance?}

GRADEMARK REPORT

FINAL GRADE

GENERAL COMMENTS

$/ 100$

Instructor

PAGE 1

PAGE 2

PAGE 3

PAGE 4

PAGE 5

PAGE 6

PAGE 7

PAGE 8

PAGE 9

PAGE 10

PAGE 11

PAGE 12

PAGE 13

PAGE 14

PAGE 15

PAGE 16

PAGE 17

PAGE 18

PAGE 19 
PAGE 20

PAGE 21

PAGE 22

PAGE 23 